\title{
CLIMATE CHANGE EFFECT ON IRRIGATION WATER REQUIREMENT OF WHEAT AND MAIZE IN NORTHERN PART OF BANGLADESH
}

\author{
Md. Panjarul \\ Haque $^{1+}$ \\ Md. Zakir Hossain ${ }^{2}$ \\ Muhammad Ahsan \\ $\mathrm{Ali}^{3}$
}

\author{
'Irrigation and Water Management, RARS, Bangladesh Agricultural \\ Research Institute, Chittagong, Bangladesh. \\ Email:panjarulhaque@gmail.com Tel:+8801722893554 \\ ${ }^{2}$ Regional Station, Bangladesh Wheat and Maize Research Institute, \\ Shyampur, Rajshahi, Bangladesh. \\ Email:zakzuberi@gmail.com Tel: +8801710375943 \\ ${ }^{3}$ Regional Station, Bangladesh Wheat and Maize Research Institute, \\ Joydebpur, Gazipur, Bangladesh. \\ Email:ahsan_wrc@yahoo.com Tel:+8801717877826
}

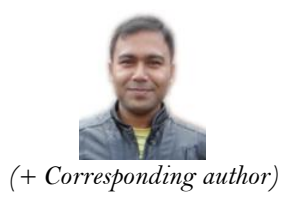

(+ Corresponding author)

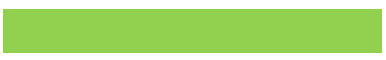

Article History

Received: 2 June 2021

Revised: 28 June 2021

Accepted: 26 July 2021

Published: 30 August 2021

\section{Keywords}

Reference evapotranspiration Crop water requirement Net irrigation water requirement Mann-Kendall test Serial correlation.

\section{ABSTRACT}

Bangladesh is one of the most vulnerable countries for climate change in agricultural water management. A research had been done to assess climate change effects on irrigation water use of wheat and maize in the northern part of Bangladesh. The twenty nine years of data (1990-2018) were analyzed with Mann-Kendall test as well as Sen's slope for climate change impact and the responsible weather parameters due to climate change were identified with correlation coefficients. The crop water requirement of wheat in Bogura and Rangpur was declining at the rate of $3.3 \mathrm{~mm}$ and $2.3 \mathrm{~mm}$ per decade respectively. Net irrigation water requirement of wheat at both Bogura and Rangpur was inclining at the rate of $1 \mathrm{~mm}$ and $10 \mathrm{~mm}$ per decade respectively because the effective rainfall of these regions was decreasing at $5 \mathrm{~mm}$ and $11 \mathrm{~mm}$ per decade respectively. The crop water requirement of maize for similar districts was increasing at the rate of $3.2 \mathrm{~mm}$ and $2.5 \mathrm{~mm}$ per decade respectively although net irrigation water requirement had statistically non-significance for climate change effect. The weather parameter, which was mainly responsible for climatic change in irrigation water requirement, was increasing temperature. Therefore, wheat cultivation might be coped with climate change in the northern part of Bangladesh rather than maize on the basis of irrigation and water management.

Contribution/Originality: The paper's primary contribution is finding that the northern region of Bangladesh might be meet up extra irrigation water demand for wheat and maize cultivation due to climate change.

\section{INTRODUCTION}

Climate change has the impact on water resources, agriculture and scio-economics etc. it increases temperature as well as anomaly rainfall and irrigation water is more vulnerable to temperature and rainfall [1].

In Bangladesh, climate change impact is susceptible for agriculture and irrigation water use. This country, about $70 \%$ of percentage of water is used for agriculture. A study performed by Delaporte and Maurel [2] found that when climate change affects one percentage point of agricultural income, then it is to mitigate the expense by three percentage points. The mean daily temperature increases $\left(0.20^{\circ} \mathrm{C}\right.$ per decade) and the rainfall increases (7.13mm per year) in monsoon and decreases $(0.75 \mathrm{~mm}$ per year) in post-monsoon which creates the flood and drought in rainy and dry seasons [3]. Bangladesh has three main cereal crops: rice, wheat, maize.Acharjee, et al. [4] found that the water requirement of rice was on a downward trend (3mm per year) in the northern part of 
Bangladesh. Haque and Chowdhury [5] studied in the southern part of Bangladesh that climate change affected the irrigation water requirement of boro rice, wheat and maize in an upward trend. So, the northern part of Bangladesh may have a critical to climate change impact in irrigation and water management of wheat and maize Figure 1.

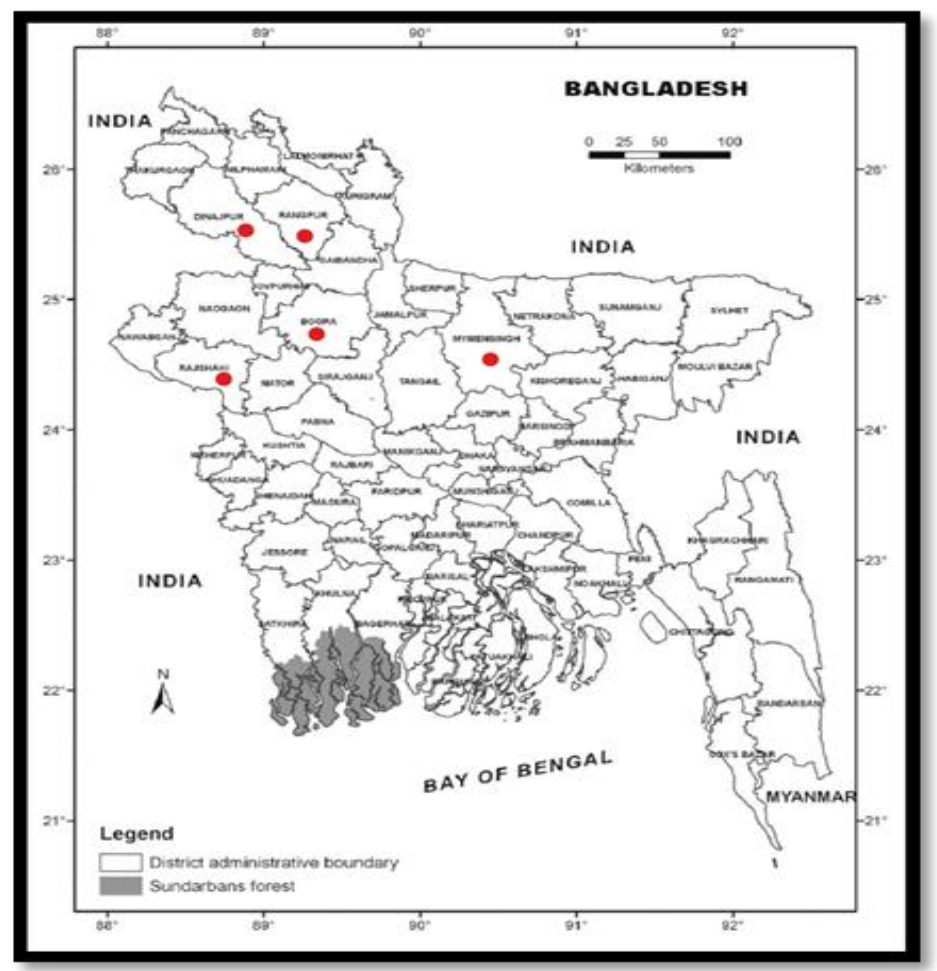

Figure-1. Bangladesh districts map and "red point "indicates research locations.

\section{MATERIALS AND METHODS}

The research work was started in July 2020 and had finished April, 2021 at regional agricultural research centre, Bangladesh Agricultural Research Institute, Chittagong.

\subsection{Data Collection}

The meteorological data: temperature, humidity, sunshine duration, wind speed and rainfall were collected over the period 1990-2018 from Bangladesh Meteorological Department, Agargaon, Dhaka. The crop related data was taken from Bangladesh Agricultural Research Institute, Gazipur, Dhaka.

\subsection{Estimation of Reference Evapotranspiration, Crop Water Requirement, Net Irrigation Water Requirement}

Reference crop evapotranspiration is the evaporative need of the surrounding atmosphere which is dependent on weather data (solar radiation, temperature, humidity and wind speed). It was calculated with the guide line of Allen, et al. [6].

$$
E T_{0}=\frac{0.408(R n-G)+\gamma \frac{900}{T+273} u 2(e s-e a)}{\Delta+\gamma(1+0.34 u 2)}
$$

Where, $\mathrm{ET}_{\mathrm{o}}=$ Reference crop evapotranspiration $(\mathrm{mm}), \mathrm{R}_{\mathrm{n}}=$ net radiation at crop surface $\left(\mathrm{MJm}^{-2} \mathrm{day}^{-1}\right), \mathrm{G}=$ soil heat flux density $\left(\mathrm{MJm}^{-2} \mathrm{day}^{-1}\right), \mathrm{T}=$ mean daily air temperature $\left({ }^{\circ} \mathrm{C}\right), \mathrm{u}_{2}=$ wind speed at $2 \mathrm{~m}$ height $\left(\mathrm{ms}^{-1}\right), \mathrm{e}_{\mathrm{s}}=$ saturation vapour pressure $(\mathrm{kPa}), \mathrm{e}_{\mathrm{a}}=$ actual vapor pressure $(\mathrm{kPa}), \Delta=$ slope of vapor pressure curve $\left(\mathrm{kPa} /{ }^{\circ} \mathrm{C}\right), \gamma=$ 
psychrometric constant $\left(\mathrm{kPa} /{ }^{\circ} \mathrm{C}\right)$. Crop water requirement is the evaporative demand of both atmosphere and plant. It was estimated with the product of crop factor and reference evapotranspiration in the following Equation $2[7]$.

$$
E T_{c}=K_{c} \times E T_{0}
$$

Where, ETc $=$ Crop water requirement $(\mathrm{mm}), \mathrm{Kc}=$ crop coefficient for - wheat: $0.7,1.15$, and 0.25 in initial, midseason, and late-season respectively- maize: 0.3, 1.2, 0.6, and 0.35 in initial stage, development stage, mid-season, and late-season respectively [7].

The net irrigation water requirement is the actual demand of irrigation water. It was determined by Equation $3[8]$.

$$
N I R=E T_{c}-P_{\text {eff }}
$$

Where, NIR=Net irrigation water requirement $(\mathrm{mm}), \mathrm{P}_{\text {effi }}=$ effective rainfall which is part of rainfall is used for plants and it was assumed $70 \%$ of rainfall [9].

\subsection{Climate Change Effects' Analysis}

2.3.1. Serial Correlation Test

Firstly, the time series data were tested for serial correlation with autocorrelation function at different lags since the existence of serial correlation influences more trend or rate of change due to climate change effect [10]. Autocorrelation function $(\mathrm{ACF})$ at lag $\mathrm{k}\left(\mathrm{r}_{\mathrm{k}}\right)$ was calculated with Equation 4.

$$
r_{k}=\frac{s_{k}}{s_{o}}
$$

Where, $\mathrm{s}_{\mathrm{k}}=$ Auto-covariance function at lag $\mathrm{k}$ which was determined by Equation $5, \mathrm{~s}_{0}=$ variance of time series.

$$
s_{k}=\frac{1}{n} \sum_{i=k+1}^{n}\left(y_{i}-y_{m}\right)\left(y_{i-k}-y_{m}\right)
$$

Where, $\mathrm{y}_{\mathrm{m}}=$ mean of time series

The plot of $r_{k}$ against lag $k$ was correlogram, which showed autocorrelation, crossing the upper and lower limits' lines. The standard error (SE) and confidence interval (CI) of the autocorrelation function at lag $\mathrm{k}$ were in Equation 6 and 7 respectively. If time series have autocorrelation or serial correlation, the data should be prewritten with the outlying of Gocic and Trajkovic [11].

$$
\begin{aligned}
& S E_{k}=\sqrt{\frac{1+2 \sum_{i=1}^{k-1} A C F(i)}{n}} \\
& C I_{k}= \pm z_{\text {crit }} \times S E_{k}
\end{aligned}
$$

\subsubsection{Trend Detection and Rate of Change's Estimation}

Mann-Kendall trend test was carried out whether there was any tend in crop water requirement, net irrigation water requirement, and irrigation parameter and the rate of change in time series data was estimated with sen's slope, shown in Equation 8, which is non-parametric method with the framework of Gocic and Trajkovic [11].

$$
\text { Sen'sSlope }=\text { Median }\left\{\frac{x_{j}-x_{i}}{j-i} ; i<j\right\}
$$

The confidence interval $(1-\alpha)$ for sen's slope: $=C(n, 2) ; k=$ se $\times z_{\text {crit }}$; lower $=\frac{x_{N-k}}{2} ;$ upper $=\frac{x_{N+k}}{2}$

Where, se=the standard error of Mann-Kendall test [10]. 


\subsubsection{Identification of Responsible Parameters for Variability}

The climatic parameters (temperature, humidity, sunshine hour, wind speed) was more dominantly cause in changing the crop water requirement, net irrigation water requirement, and irrigation parameter-was determined with the correlation coefficient $\left(\mathrm{r}_{\mathrm{xy}}\right)$ among them Equation 9 .

$$
r_{x y}=\frac{N^{\prime} \sum X Y-\left(\sum X\right)\left(\sum Y\right)}{\sqrt{\left[N^{\prime} \sum X^{2}-\left(\sum X\right)^{2}\right]\left[N^{\prime} \sum Y^{2}-\left(\sum Y\right)^{2}\right]}}
$$

Where, $\mathrm{X}=$ temperature, humidity, sunshine hour, wind speed and $\mathrm{Y}=$ reference crop evapotranspiration, crop water requirement, net irrigation water requirement and effective rainfall. The significance of $r_{x y}$ was computed with Pearson's product- moment method. If the value of $\mathrm{r}$ with Pearson's product- moment method at level of (N'2df) is less than the calculated with Equation 9, then the $\mathrm{X}$ and $\mathrm{Y}$ has significantly the correlation [12].

\subsection{Data Analysis}

The data of research work was analyzed and made graphs with Microsoft Excel 2007 and R version 4.0.2 software "modifiedmk", "trend change" as well as "Hmisc" packages.

\section{RESULTS AND DISCUSSION}

\subsection{Serial Correlation Test}

The serial correlation was identified with different lags of time series data: net irrigation water requirement (NIR), crop water requirement (ETc), and reference evapotranspiration $\left(\mathrm{ET}_{0}\right)$ by autocorrelation function (ACF). Almost all time series data was serial correlation free since there was no cross the boundary limit of autocorrelation at lag-1 which is shown in Figure 2, Figure 3 and Figure 4. The data crossing the limit was prewritten by guidance of Gocic and Trajkovic [11], otherwise it yielded more trend and rate of change.
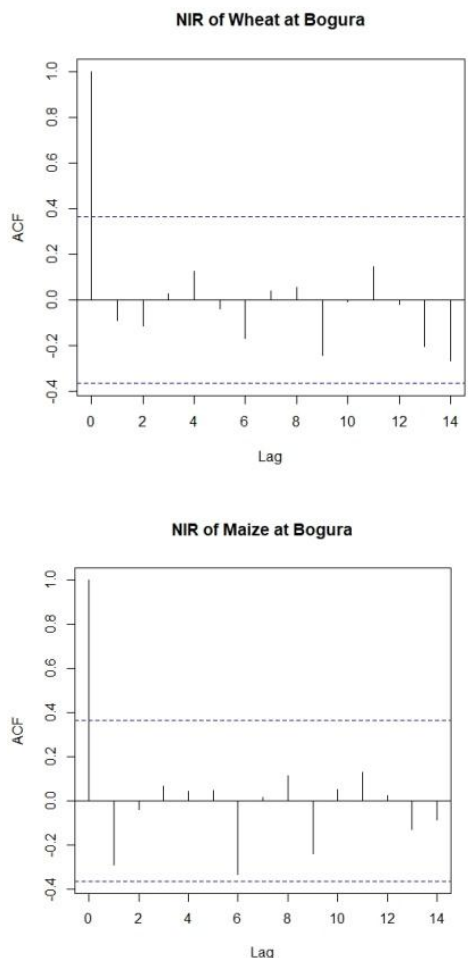

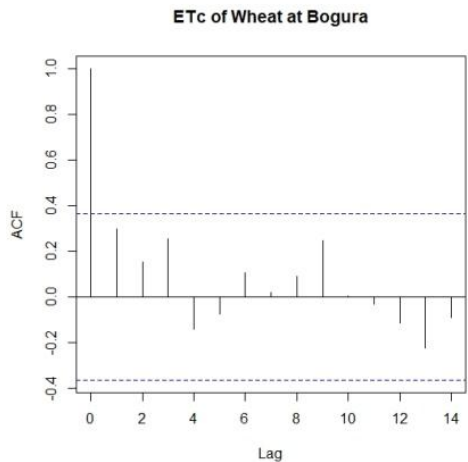

ETc of Maize at Bogura

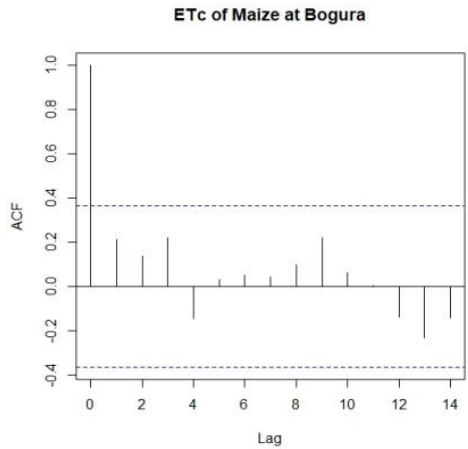

Lag

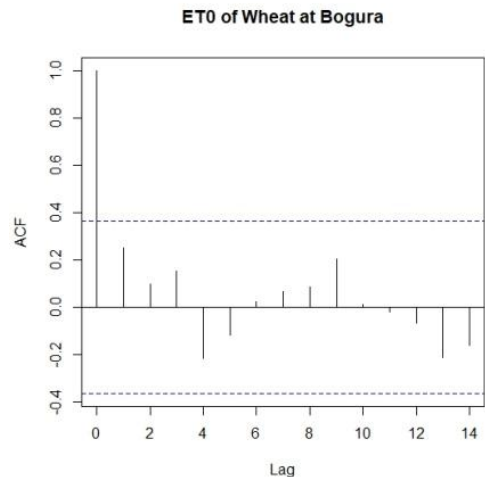

Lag

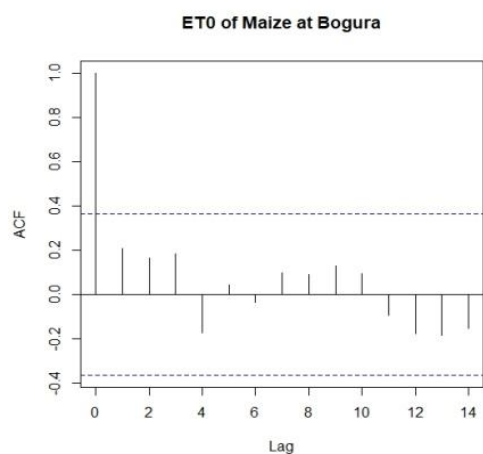

Lag

Figure-2. Autocorrelation $(\mathrm{ACF})$ of net irrigation water requirement (NIR), crop water requirement (ETc), reference evapotranspiration (ET $)$ with different lags at Bogura from 1990 to 2018. 
NIR of Wheat at Dinajpur

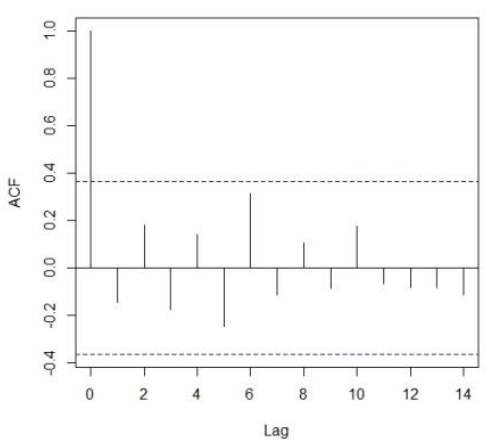

NIR of Maize at Dinajpur

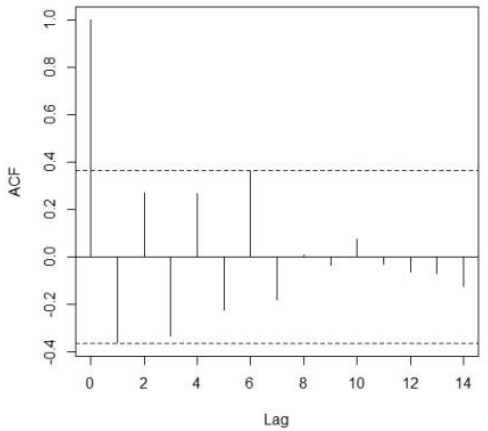

NIR of Wheat at Mymensingh

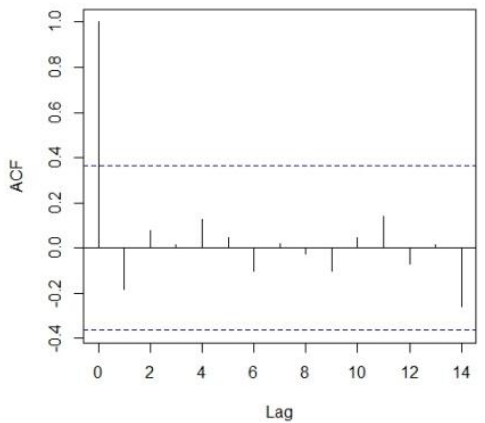

NIR of Maize at Mymensingh

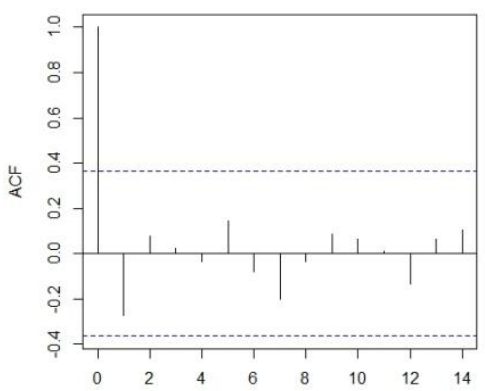

Lag

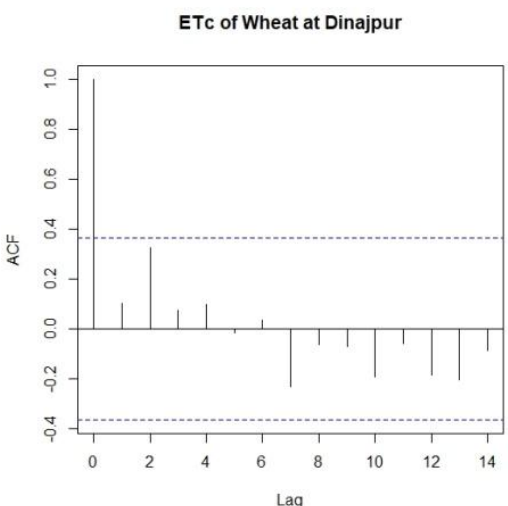

ETC of Maize at Dinajpur

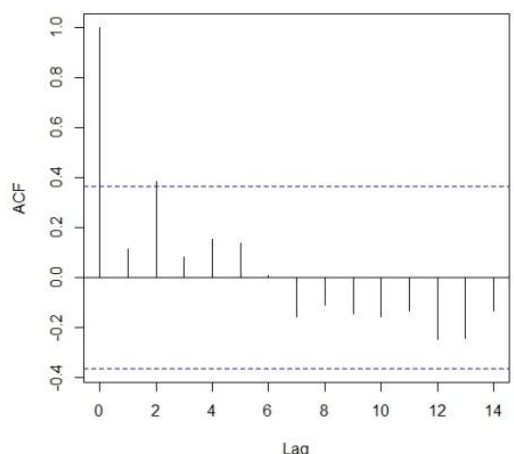

ETC of Wheat at Mymensingh

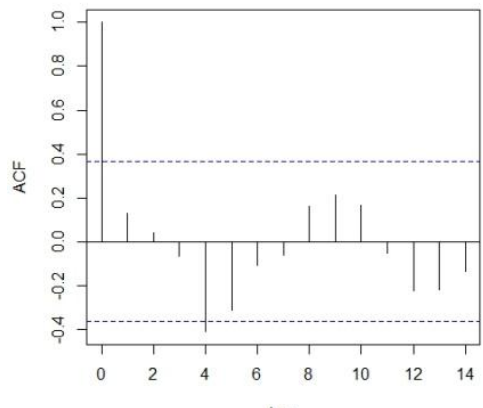

Lag

ETc of Maize at Mymensingh

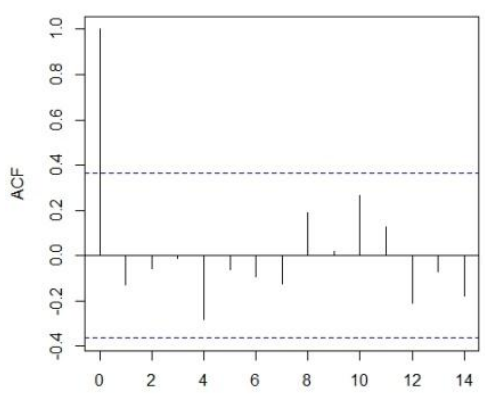

Lag

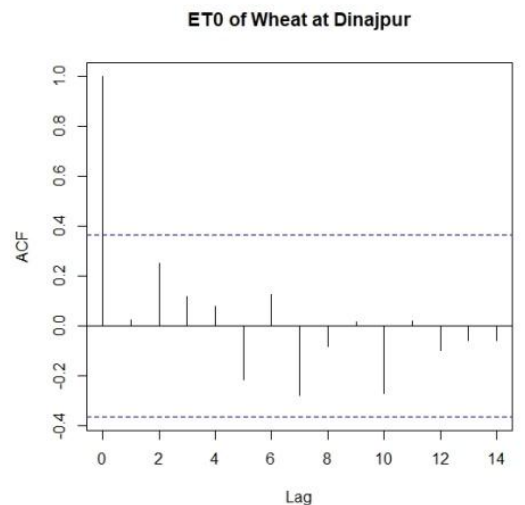

ET0 of Maize at Dinajpur

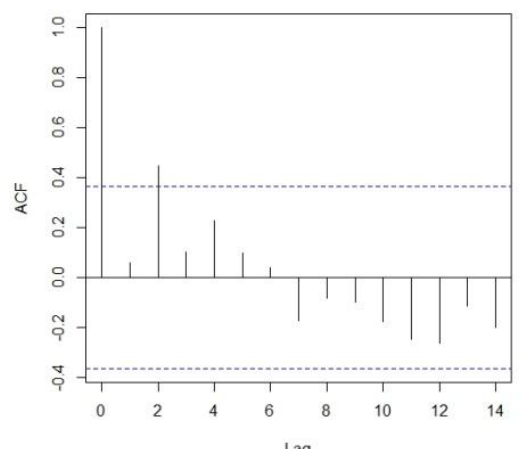

Lag

ETO of Wheat at Mymensingh

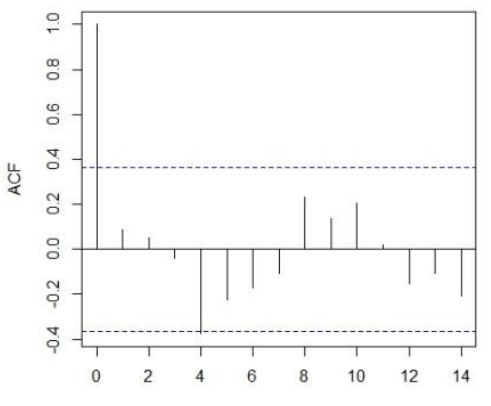

Lag

ETO of Maize at Mymensingh

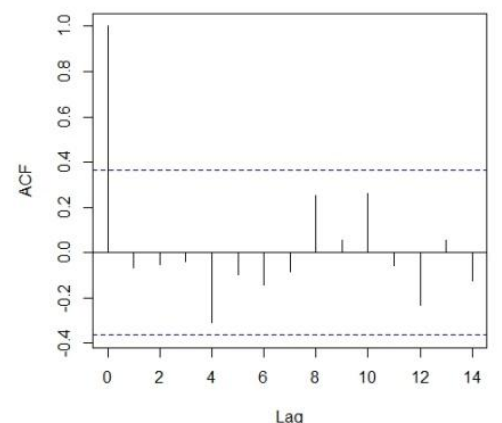

Figure-3. Autocorrelation $(\mathrm{ACF})$ of net irrigation water requirement $(\mathrm{NIR})$, crop water requirement (ETc), reference evapotranspiration $\left(\mathrm{ET}_{0}\right)$ with different lags Dinajpur and Mymensingh from 1990 to 2018. 
NIR of Wheat at Rajshahi

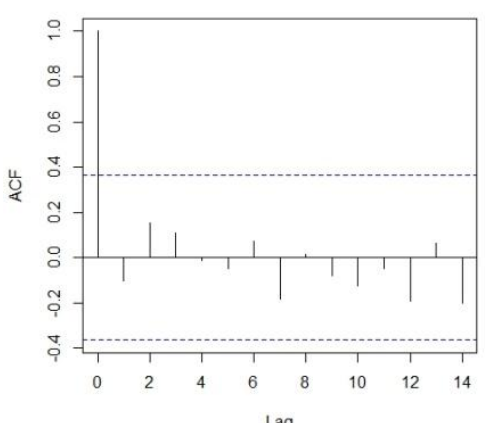

NIR of Maize at Rajshahi

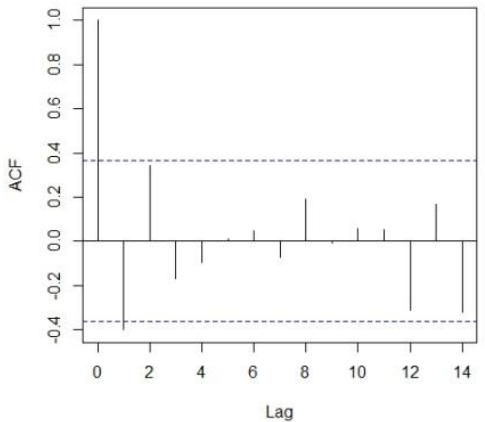

NIR of Wheat at Rangpur

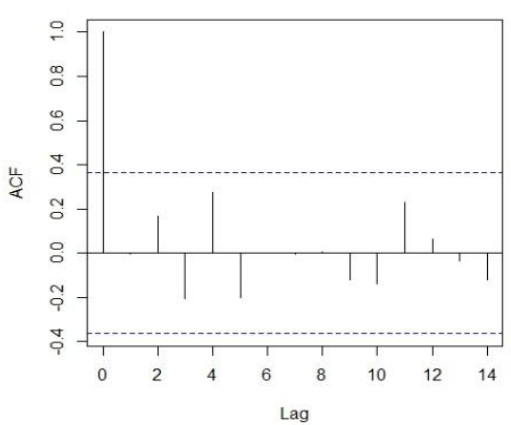

NIR of Maize at Rangpur

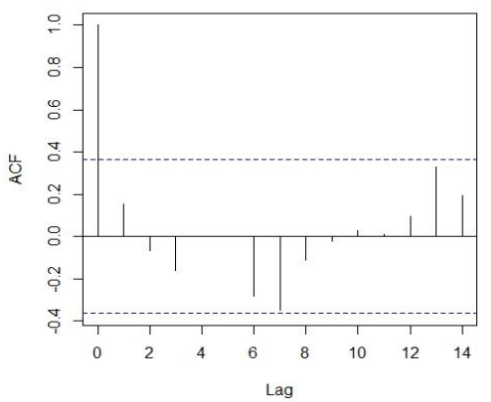

ETC of Wheat at Rajshah

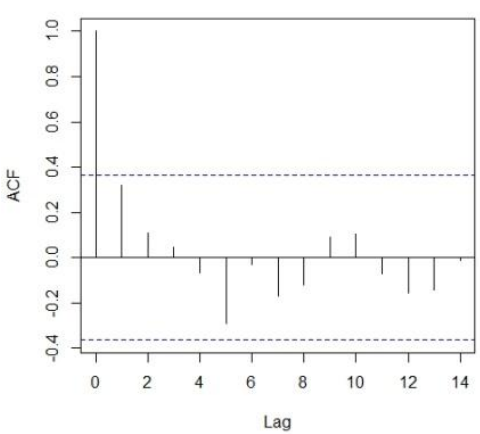

ETC of Maize at Rajshahi

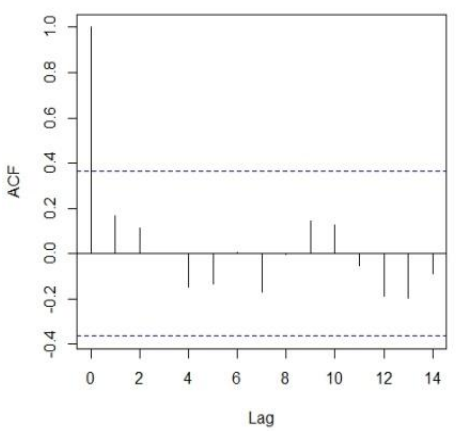

ETC of Wheat at Rangpur

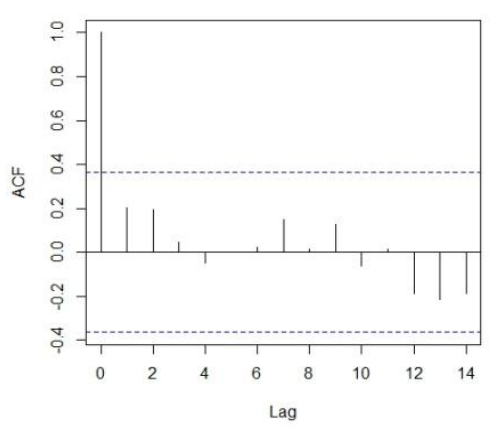

ETc of Maize at Rangpur

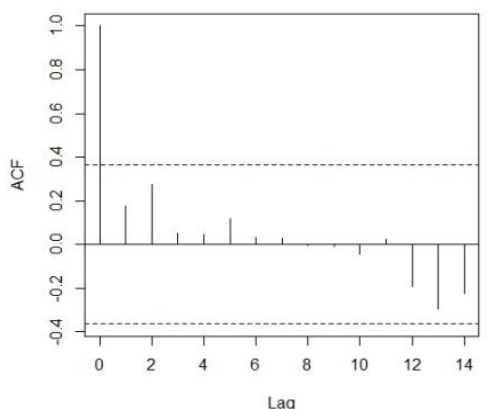

ETO of Wheat at Rajshahi

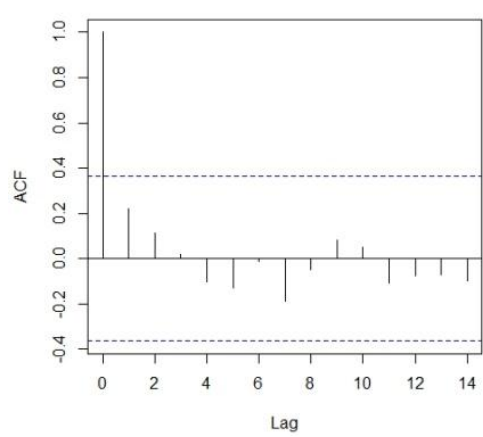

ET0 of Maize at Rajshahi

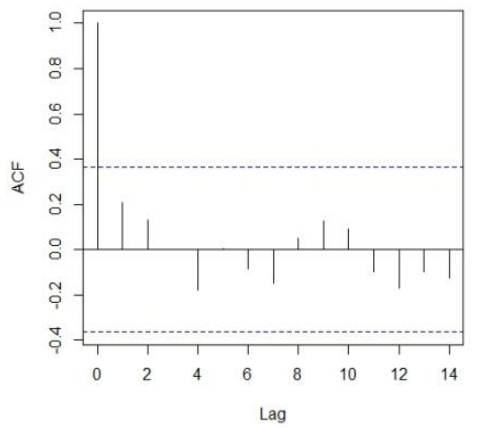

ETO of Wheat at Rangpur

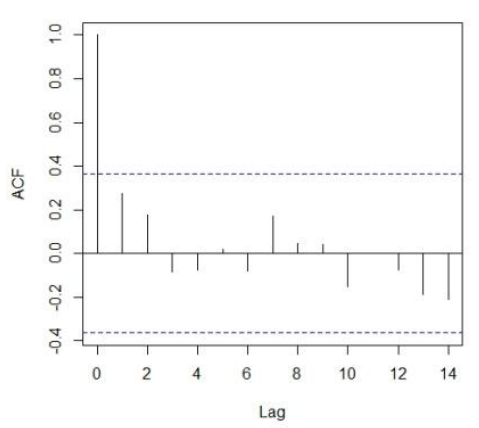

ET0 of Maize at Rangpur

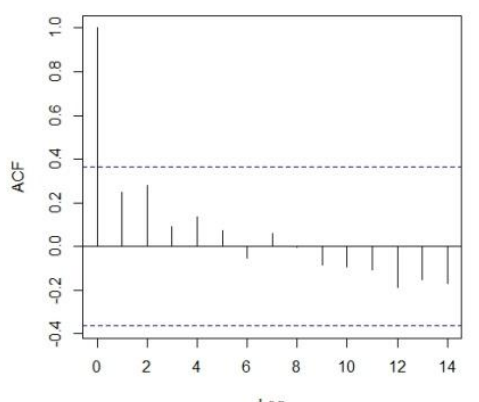

Lag

Figure-4. Autocorrelation (ACF) of net irrigation water requirement (NIR), crop water requirement (ETc), reference evapotranspiration (ET $)$ with different lags at Rajshahi and Rangpur from 1990 to 2018.

3.2. Reference Evapotranspiration (ETo), Crop Water Requirement (ETc) and Net Irrigation Water Requirement (NIR)

Reference evapotranspiration $\left(\mathrm{ET}_{0}\right)$ during wheat and maize cultivation was the lowest (1420mm and $2500 \mathrm{~mm}$ respectively) at Rangpur and highest $(1552 \mathrm{~mm}$ and $2737 \mathrm{~mm}$ respectively) at Rajshahi Figure 5 because the temperature at Rajshahi was higher than Rangpur. Mojid, et al. [13] showed the evidence of the similar results. The crop water requirement of both wheat and maize ranged from $268 \mathrm{~mm}$ at Rangpur to $292 \mathrm{~mm}$ at Rajshahi and 
$302 \mathrm{~mm}$ at Rangpur to $360 \mathrm{~mm}$ at Rajshahi respectively. The results were coincident with Schulthess, et al. [14] which studied in coastal areas in Bangladesh. Net irrigation water requirement of wheat and maize was also high (266 $\mathrm{mm}$ and $318 \mathrm{~mm}$ respectively) at Rajshahi since the temperature was higher and effective rainfall is lower than any regions.

wheat $=$ Maize
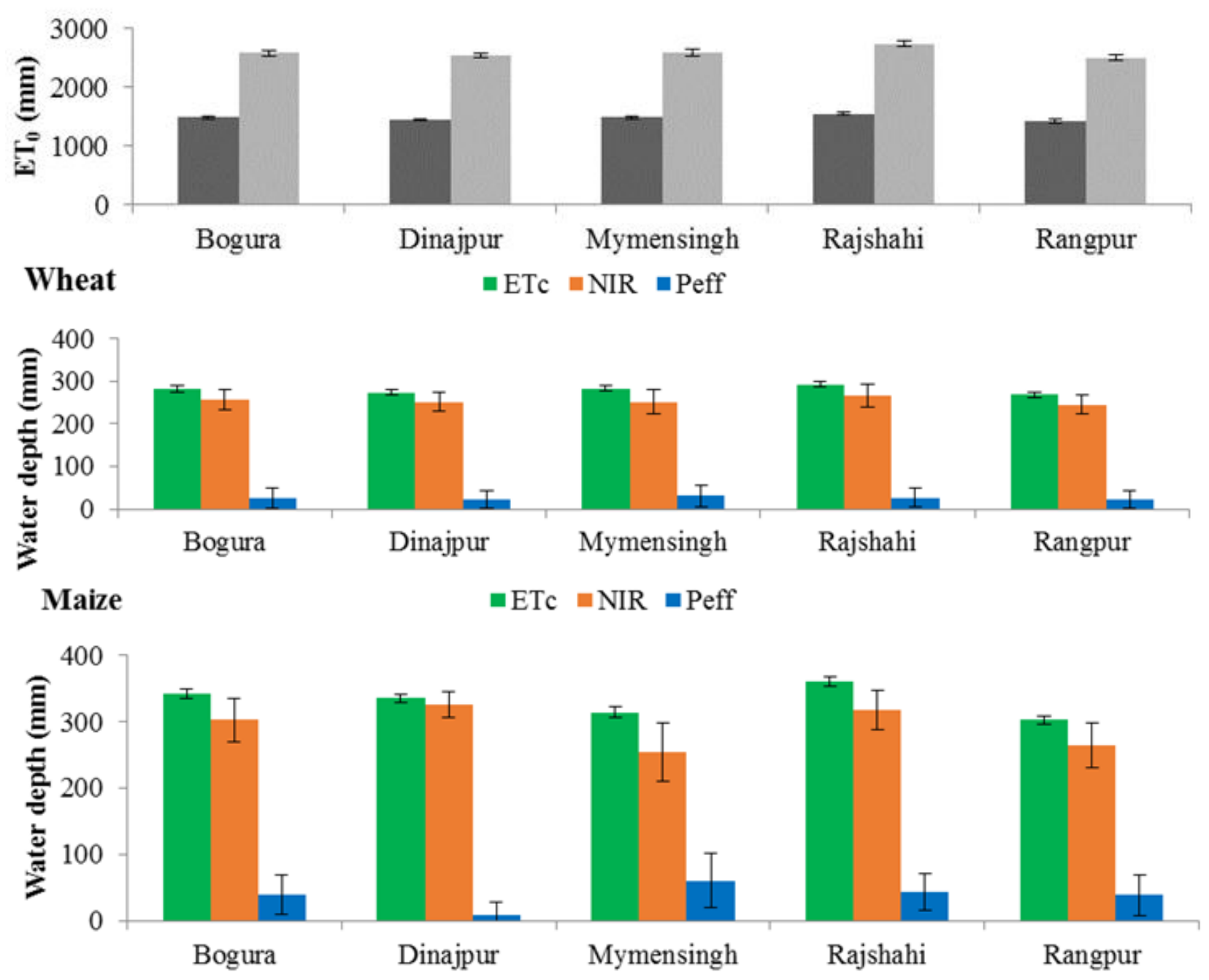

Figure-5. Mean reference crop evapotranspiration $\left(\mathrm{ET}_{\mathrm{o}}\right)$, crop water requirement $(\mathrm{ETc})$, effective rainfall ( $\mathrm{P}_{\mathrm{eff}}$ ), net irrigation water requirement (NIR) of wheat and maize from 1990 to 2018. Bar sign indicates the standard deviation.

\subsection{Climate Change Effect on Irrigation Water of Wheat and Maize}

Net irrigation water demand was dependent upon the reference evapotranspiration (ETo), crop water requirement $(\mathrm{ETc})$ and effective rainfall. When the climatic change affected those parameters, Irrigation water requirement had a change. During the period of wheat and maize, $\mathrm{ET}_{\mathrm{o}}$ had no trend and the rate of change was statistically significant. The crop water requirement of both crops had no trend at Dinajpur, Mymensingh and Rajshahi. Moreover, Bogura and Rangpur had the declining trend of ETc at 95\% and 90\% confidence intervals. Acharjee, et al. [4] had the same findings in the case of boro rice production. The rate of change for both wheat and maize at Bogura and Rangpur was about 3.3 and $2.5 \mathrm{~mm}$ per decade respectively. The trend of effective rainfall during wheat cultivation had no significance except for Rangpur at $1 \%$ level of significance. On the other hand, there was no trend of effective rainfall in maize production Table 1. Net irrigation water requirement (NIR) was no trend in Maize cultivation and for wheat production, NIR at bogura an Rangpur had an upward trend which was $1 \mathrm{~mm}$ and $10 \mathrm{~mm}$ per decade at $90 \%$ and $95 \%$ confidence interval. Therefore, wheat production might be discouraged 
at Bogura and Rangpur on the basis of irrigation water requirement because of extra demand of irrigation in near future. NIR of wheat was also the upward trend in the southern part of Bangladesh [5].

Table-1. Rate of Change at Reference crop evapotranspiration, effective rainfall, crop water requirement and net irrigation requirement in different districts from 1990 to 2018.

\begin{tabular}{l|c|c|c|c|c|c|c|c}
\hline & \multicolumn{4}{|c|}{ Wheat } & \multicolumn{3}{c}{ Maize } \\
\hline & ET $_{\mathbf{0}}$ & P $_{\text {eff }}$ & ETc & NIR & ET $_{\text {o }}$ & Peff $^{\text {ETc }}$ & NIR \\
\hline Bogura & -0.97 & -0.5 & $-0.33^{*}$ & $0.01+$ & $-1.79^{*}$ & -0.31 & $-0.32^{*}$ & -0.21 \\
\hline Dinajpur & -0.18 & -0.45 & -0.18 & 0.35 & -0.65 & -0.06 & -0.24 & 0.19 \\
\hline Mymensingh & 0.65 & -0.96 & -0.01 & 0.97 & 0.3 & -1.2 & 0.01 & 0.8 \\
\hline Rajshahi & 0.55 & -0.7 & 0.026 & 0.65 & 0.4 & -0.77 & 0.02 & 0.72 \\
\hline Rangpur & -0.91 & $-1.1^{*} *$ & $-0.23+$ & $0.9^{*}$ & -1.56 & -0.34 & $-0.25+$ & -0.1 \\
\hline
\end{tabular}

Note: $\mathrm{ET}_{0}=$ Reference crop evapotranspiration; ETc= Crop water requirement; $\mathrm{P}_{\text {eff }}=$ effective rainfall; NIR= Net irrigation requirement; “+”,"*”,"***, are $10 \%, 5 \%, 1 \%$ level of significance.

Table-2. Correlation coefficient $\left(\mathrm{r}_{\mathrm{xy}}\right)$ of reference crop evapotranspiration $\left(\mathrm{ET}_{\mathrm{o}}\right)$, crop water requirement (ETc), effective rainfall ( $\left.\mathrm{P}_{\mathrm{eff}}\right)$ and net irrigation water requirement (NIR) with relative humidity, temperature, Sunshine and wind speed at district and crop wise.

\begin{tabular}{|c|c|c|c|c|c|c|c|c|}
\hline & & & RH & Tmax & Tmin & Sunshine & Wind & Responsible parameters for variation \\
\hline \multirow{8}{*}{ 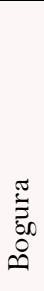 } & \multirow{4}{*}{ 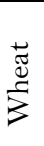 } & NIR & -0.28 & $0.63^{* *}$ & $0.37^{*}$ & 0.16 & -0.05 & Maximum and minimum temperature \\
\hline & & ETc & 0.05 & $0.73^{*} *$ & 0.01 & $0.46^{*}$ & -0.13 & Maximum temperature and sunshine hours \\
\hline & & ETo & 0.08 & $0.77^{*} *$ & 0.09 & $0.4^{*}$ & $\mathrm{O}$ & Maximum temperature and sunshine hours \\
\hline & & Peff & 0.31 & $-0.48^{*} *$ & $-0.4^{*}$ & -0.04 & 0.02 & Maximum and minimum temperature \\
\hline & \multirow{4}{*}{$\stackrel{\stackrel{N}{\mathbb{E}}}{\Sigma}$} & NIR & $-0.41^{*}$ & $0.66^{* *}$ & 0.24 & 0.08 & 0.01 & Relative humidity and maximum temperature \\
\hline & & ETc & 0.02 & $0.74^{*} *$ & 0.04 & $0.46^{*}$ & -0.11 & Maximum temperature and sunshine hours \\
\hline & & ETo & -0.01 & $0.72^{*} *$ & -0.01 & $0.38^{*}$ & 0.04 & Maximum temperature and sunshine hours \\
\hline & & Peff & $0.45^{*}$ & $-0.55^{* *}$ & -0.25 & 0.01 & -0.03 & Relative humidity and maximum temperature \\
\hline \multirow{8}{*}{ 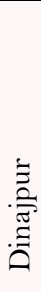 } & \multirow{4}{*}{$\frac{\sqrt[J]{J}}{3}$} & NIR & -0.12 & 0.24 & -0.17 & -0.2 & 0.31 & - \\
\hline & & ETc & -0.1 & $0.69^{* *}$ & -0.18 & 0.31 & -0.06 & Maximum temperature \\
\hline & & ETo & 0.04 & $0.5^{* *}$ & -0.2 & 0.18 & 0.04 & Maximum temperature \\
\hline & & Peff & 0.11 & -0.06 & 0.14 & 0.31 & -0.36 & - \\
\hline & \multirow{4}{*}{$\stackrel{\stackrel{N}{*}}{\stackrel{\Xi}{\Sigma}}$} & NIR & -0.2 & 0.28 & -0.21 & -0.24 & 0.18 & - \\
\hline & & ETc & -0.24 & $0.77^{*} *$ & -0.15 & 0.3 & -0.04 & Maximum temperature \\
\hline & & ETo & -0.3 & $0.67^{*} *$ & -0.25 & 0.22 & 0.08 & Maximum temperature \\
\hline & & Peff & 0.12 & -0.01 & 0.17 & 0.37 & -0.21 & - \\
\hline \multirow{8}{*}{ 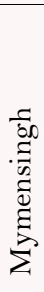 } & \multirow{4}{*}{$\frac{\stackrel{\pi}{ \pm}}{\sum}$} & NIR & 0.15 & $0.57 * *$ & 0.2 & 0.1 & -0.03 & Maximum temperature \\
\hline & & ETc & 0.23 & $0.74^{* * *}$ & 0.16 & 0.24 & -0.13 & Maximum temperature \\
\hline & & ETo & 0.23 & $0.78^{*} *$ & 0.19 & 0.23 & -0.16 & Maximum temperature \\
\hline & & Peff & -0.11 & $-0.46^{*}$ & -0.19 & -0.05 & $\mathrm{O}$ & Maximum temperature \\
\hline & \multirow{4}{*}{ 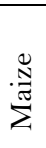 } & NIR & 0.06 & $0.55^{* *}$ & 0.12 & 0.11 & $-0.38^{*}$ & Maximum temperature and wind speed \\
\hline & & ETc & -0.03 & $0.85^{* * *}$ & 0.07 & 0.36 & -0.3 & Maximum temperature \\
\hline & & ETo & $\mathrm{O}$ & $0.8^{*} * *$ & $\mathrm{O}$ & 0.21 & -0.36 & Maximum temperature \\
\hline & & Peff & -0.07 & $-0.44^{*}$ & -0.11 & -0.06 & 0.36 & Maximum temperature \\
\hline \multirow{8}{*}{ 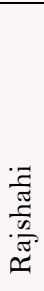 } & \multirow{4}{*}{ 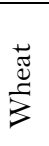 } & NIR & -0.08 & $0.68^{*} *$ & 0.17 & 0.1 & 0.1 & Maximum temperature \\
\hline & & ETc & 0.09 & $0.6^{* * *}$ & -0.34 & -0.02 & $0.58^{* *}$ & Maximum temperature and wind speed \\
\hline & & ETo & 0.13 & $0.69^{* *}$ & -0.23 & -0.11 & $0.63^{* * *}$ & Maximum temperature and wind speed \\
\hline & & Peff & 0.11 & $-0.59^{* *}$ & -0.28 & -0.12 & 0.05 & Maximum temperature \\
\hline & \multirow{4}{*}{$\stackrel{\stackrel{N}{J}}{\Sigma}$} & NIR & -0.29 & $0.68^{*} *$ & 0.18 & 0.12 & 0.12 & Maximum temperature \\
\hline & & ETc & -0.04 & $0.65 * *$ & -0.25 & -0.03 & 0.57 *** & Maximum temperature and wind speed \\
\hline & & ETo & -0.01 & $0.68^{* *}$ & -0.19 & -0.17 & $0.67^{* *}$ & Maximum temperature and wind speed \\
\hline & & Peff & 0.31 & $-0.57 * *$ & -0.26 & -0.13 & 0.02 & Maximum temperature \\
\hline \multirow{8}{*}{ 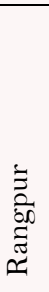 } & \multirow{4}{*}{$\frac{\sqrt[\pi]{J}}{3}$} & NIR & -0.28 & $0.53^{* *}$ & 0.19 & -0.04 & 0.15 & Maximum temperature \\
\hline & & ETc & -0.05 & $0.64^{* * *}$ & -0.11 & $0.39 *$ & 0.17 & Maximum temperature and sunshine hours \\
\hline & & ETo & $\mathrm{O}$ & $0.69^{*} *$ & -0.04 & $0.38^{*}$ & 0.24 & Maximum temperature and sunshine hours \\
\hline & & Peff & 0.28 & $-0.4^{*}$ & -0.22 & 0.14 & -0.11 & Maximum temperature \\
\hline & \multirow{4}{*}{$\underbrace{\stackrel{\Xi}{J}}_{\Sigma}$} & NIR & $-0.53^{*} *$ & $0.5^{*} * *$ & -0.02 & 0.23 & -0.08 & Relative humidity and maximum temperature \\
\hline & & ETc & -0.23 & $0.73^{* *}$ & -0.15 & 0.36 & 0.06 & Maximum temperature \\
\hline & & ETo & -0.23 & $0.68^{* * *}$ & -0.24 & $0.39^{*}$ & 0.14 & Maximum temperature and sunshine hours \\
\hline & & Peff & $0.51^{* *}$ & $-0.39^{*}$ & -0.01 & -0.17 & 0.09 & Relative humidity and maximum temperature \\
\hline
\end{tabular}

Note: RH=Relative humidity, Tmax and Tmin= maximum and minimum temperature respectively, The notation $*$ and $* *$ is at $5 \%$ and $1 \%$ level of significance respectively. 


\subsection{Climate Change-Responsible Parameters for Variability}

Irrigation parameters were estimated with the help of weather data (temperature, humidity, sunshine duration, wind speed). The maximum temperature was the main cause of variability in reference crop evapotranspiration $\left(\mathrm{ET}_{\mathrm{o}}\right)$, crop water requirement $(\mathrm{ETc})$, effective rainfall $\left(\mathrm{P}_{\mathrm{eff}}\right)$ and net irrigation water requirement (NIR) due to climate change. Table was showed the responsible climatic data in irrigation parameters. The variability of $\mathrm{ET}_{0}$ was the combined effect of temperature, sunshine and wind speed Table 2. The results were similar to Mojid, et al. [13] as well as Haque and Chowdhury [5]. So, the maximum temperature in this region played a vital role in changing the irrigation water parameters.

\section{CONCLUSION}

The purpose of research is to evaluate the climatic change impact on irrigation water requirement of wheat and maize in the northern region of Bangladesh. The crop water requirement of wheat and maize was the increasing rate of approximately $3 \mathrm{~mm}$ per decade due to climate change in both Bogura and Rangpur districts. But the net irrigation water requirement of wheat had only the climate change impact in Bogura (1mm per decade) and Rangpur (10mm per decade) at $10 \%$ and $5 \%$ levels of significance. Net irrigation water requirement of maize was non-significance of climatic change. The temperature (especially maximum temperature) was the dominant parameter for climate change effect on irrigation water requirement in the northern region of Bangladesh. Therefore, due to climate change impact, wheat cultivation at Bogura and Rangpur would require extra 10,000 liters and 100000 liters irrigation water per hectare respectively for every ten years later. In the future, irrigation projects like Teesta barrage irrigation project should be considered for this extra irrigation water requirement in water resources planning for wheat production.

Funding: This study received no specific financial support.

Competing Interests: The authors declare that they have no competing interests

Acknowledgement: All authors contributed equally to the conception and design of the study.

\section{REFERENCES}

[1] K. D. Frederick and D. C. Major, "Climate change and water resources," Clim Change, vol. 37, pp. 7-23, 1997.Available at: https://doi.org/10.1023/A:1005336924908.

[2] I. Delaporte and M. Maurel, "Adaptation to climate change in Bangladesh," Clim Policy vol. 18, pp. 49-62, 2018.Available at: https://doi.org/10.1080/14693062.2016.1222261.

[3] M. R. Rahman and H. Lateh, "Climate change in Bangladesh: A spatio-temporal analysis and simulation of recent temperature and rainfall data using GIS and time series analysis model," Theoretical and Applied Climatology, vol. 128, pp. 27-41, 2017.Available at: https://doi.org/10.1007/s00704-015-1688-3.

[4] T. K. Acharjee, G. v. Halsema, F. Ludwig, and P. Hellegers, "Declining trends of water requirements of dry season boro rice in the north-west Bangladesh," Agric. Water Manag, vol. 180, pp. 148-159, 2017.Available at: https://doi.org/10.1016/j.agwat.2016.11.014.

[5] M. P. Haque and S. M. K. H. Chowdhury, "Trend of irrigation water requirement in halda river basin of Bangladesh," Journal of Science, Technology and Environment Informatics, vol. 10, pp. 673-684, 2020.Available at: https://doi.org/10.18801/jstei.100120.68.

[6] R. G. Allen, L. S. Pereira, D. Raes, and M. Smith, "Crop evapotranspiration-Guidelines for computing crop water requirements-FAO Irrigation and drainage paper 56," Fao, Rome, vol. 300, p. Do5 109, 1998.

[7] A. P. Savva and K. Frenken, "Crop water requirements and irrigation scheduling, Fao, Rome, Italy, Irrigation manual 4. Retrieved from: http://www.fao.org/3/ai593e/ai593e.pdf," 2002.

[8] C. Brouwer, K. Prins, and M. Heibloem, "Irrigation water management: Irrigation scheduling, Fao, Rome, Italy, Training manual module 4. Retrieved from: http://www.fao.org/3/T7202E/T7202E00.htm," 1989. 
[9] A. Singh, "Optimizing the use of land and water resources for maximizing farm Income by mitigating the hydrological imbalances," Journal of Hydrologic Engineering, vol. 19, pp. 1447-1451, 2014.Available at: https://doi.org/10.1061/(ASCE)HE.1943-5584.0000924.

[10] K. H. Hamed and A. Ramachandra Rao, "A modified Mann-Kendall trend test for autocorrelated data," Journal of Hydrology, vol. 204, pp. 182-196, 1998.Available at: https://doi.org/10.1016/So022-1694(97)00125-X.

[11] M. Gocic and S. Trajkovic, "Analysis of changes in meteorological variables using Mann-Kendall and Sen's slope estimator statistical tests in Serbia," Global and Planetary Change, vol. 100, pp. 172-182, 2013.Available at: https://doi.org/10.1016/j.gloplacha.2012.10.014.

[12] G. Ray and S. Mondal, Research methods in social science and extension education. New Delhi, India: Kalyani Publishers, 2004.

[13] M. A. Mojid, R. P. Rannu, and N. N. Karim, "Climate change impacts on reference crop evapotranspiration in NorthWest hydrological region of Bangladesh," International Journal of Climatology, vol. 35, pp. 4041-4046, 2015.Available at: https://doi.org/10.1002/joc.4260.

[14] U. Schulthess, Z. U. Ahmed, S. Aravindakshan, G. M. Rokon, A. S. M. Alanuzzaman Kurishi, and T. J. Krupnik, "Farming on the fringe: Shallow groundwater dynamics and irrigation scheduling for maize and wheat in Bangladesh's coastal delta," Field Crops Research - Journal, vol. 239, pp. 135-148, 2019.Available at: https://doi.org/10.1016/j.fcr.2019.04.007.

Views and opinions expressed in this article are the views and opinions of the author(s), International Journal of Climate Research shall not be responsible or answerable for any loss, damage or liability etc. caused in relation to/arising out of the use of the content. 